\title{
3-4aastaste eesti laste kõne grammatiline profiil
}

\author{
Marika Padrik $^{\text {a1 }}$, Merit Hallapa ${ }^{\mathrm{a}}$, Signe Raudik \\ ${ }^{a}$ Tartu Ülikooli haridusteaduste instituut
}

\begin{abstract}
Annotatsioon
Töö eesmärk on kirjeldada ja võrrelda eakohase ja hilistunud kõnearengu grammatilisi profiile ning leida tunnused, mille alusel on võimalik eristada kõne arengu poolest riskirühma kuuluvaid lapsi. Meetodiks on pöörd- ja käändsõnavormide kasutuse ning lauseloome suunatud esilekutsumine ja järelekordamine. Uurimuse valimi moodustavad 149 3aastast ja 186 4aastast eakohase arenguga last. Kontrollrühmaks on 61 kõne arengu hilistusega samaealist last. Uurimistulemustest selgub, et 3- ja 4aastased lapsed erinevad oma grammatilise profiili poolest oluliselt, kusjuures 4aastased valdavad keelesüsteemi uuritud oskuste ja keelendite piires. Kõne arengu hilistusega laste grammatiline profiil järgib eakohase arenguga laste oma, sarnanedes nooremate laste profiiliga. Tulemused võimaldavad laste kõne arengut hindavatel spetsialistidel eristada 3-4aastaste laste grammatika arengule omaseid tüüpilisi ja ebatüüpilisi tunnuseid ning varakult märgata kõne arengu poolest riskirühma kuuluvaid lapsi.
\end{abstract}

Võtmesõnad: kõne arengu hilistumine, eakohane kõne areng, grammatiline profiil

\section{Sissejuhatus}

Lapse varane kõne areng on oluline hilisema suulise ja kirjaliku kõne taseme ning seega ka koolieedukuse ja elus toimetuleku ennustaja (Everitt, Hannaford, \& Conti-Ramsden, 2013). 3- ja 4aastastel lastel on kõne eakohase arengu oluliseks tunnuseks mitmekesine grammatiliste vahendite kasutamise oskus. Eesti keele kui morfoloogiliselt rikka keele puhul (vt Dressler, 2005; Lukács, Leonard, \& Kas, 2010) on grammatiliste oskuste hindamine ökoloogiliselt valiidne viis eristada eakohast ja hilistunud kõnearengut. 
1,5-2 aasta vanuses ilmuvad lapse kõnesse 2- ja 3sõnalised laused ning laps hakkab omandama grammatikat. 10-15\% lastest ei arene kõne ootuspäraselt (Desmarais, Sylvestre, Meyer, Bairati, \& Rouleau, 2008; Paul \& Roth, 2011). Kõne arengu mahajäämust märgitakse alates 2 aasta vanusest, kui eeldatud lihtsaid lauseid pole lapse kõnesse ilmunud. 2-4aastaste laste puhul aga on raske välja selgitada, kas tegemist on hilisema arengu või spetsiifilise kõnearengupuudega (vt Padrik, 2014). Kõne hindamiseks on vaja teada tunnuseid, mis eristavad kõnehilistusega lapsi eakohase arenguga lastest. Eelkõige inglise keele baasil tehtud uuringutest (Rescorla, 2011; Rescorla, Dahlsgaard, \& Roberts, 2000; Rescorla \& Roberts, 2002; Rescorla \& Turner, 2015; Rice, Taylor, \& Zubrick, 2008) ilmneb, et hiliskõnelejatele on iseloomulik grammatiliste oskuste, eriti verbimorfoloogia hilisem kujunemine. Just 3-4aastastel kõne arengu hilistusega lastel on grammatiliste oskuste tase eakohase arenguga laste omast madalam, samas 5-6aastastel hakkab see jõudma eakaaslastele järele. Eestis sellised uuringud puuduvad.

Eakohase kõnearenguga eesti laste grammatikat on uurinud peamiselt keeleteadlased üksikjuhtumite alusel (vt Argus, 1995, 2004, 2007, 2008; Kapanen, 2014; Vihman \& Vija, 2006). Nende uuringute põhjal on teada, mis vanuses millised lausetüübid ja sõnavormid kõnesse ilmuvad. Uuritud on lapsi vanuses 1 aasta ja 3 kuud kuni 3 aastat. Kuna tegemist on väikeste valimite ja spontaanse kõne lindistuste analüüsiga, ei saa eeldada, et kirjeldatud arengutendentsid on eesti lastele universaalselt iseloomulikud.

Kuna siiani puuduvad Eestis grammatiliste oskuste hindamise seisukohalt olulise vanuse kohta põhjalikumad andmed, mis aitaksid logopeedidel ja lasteaiaõpetajatel õigel ajal märgata ja toetada kõnelise erivajadusega lapsi, püütakse praeguse uurimusega seda lünka täita. Uurimuse eesmärk on kirjeldada ja võrrelda eakohase ja hilistunud kõnearengu grammatilisi profiile ning leida tunnused, mille alusel on võimalik eristada kõne arengu poolest riskirühma kuuluvaid lapsi.

\section{Grammatiliste oskuste varane areng}

Eesti laste varast süntaksi arengut on kahe lapse spontaanse kõne näitel kirjeldanud Kapanen (2014). Süntaksi baassuhete omandamine ehk selliste lausete moodustamine, milles on subjekt-verb, verb-objekt, algas ühel lapsel vanuses 1 aasta ja 10 kuud, teisel aga juba vanuses 1 aasta ja 3 kuud. Prototüüpseks peetav lause, milles on alus, öeldis ja sihitis, realiseerus ühe lapse kõnes esialgu kahe lausena, nt Poiss pü̈̈ab kala: kala piia [= pü̈̈a] ja poiss kala (ibid.). Arguse (1995) uuritav omandas esimesed (peamiselt 
3sõnalised) lihtlausetüübid samuti varakult - vanuses 1 aasta ja 6 kuud kuni 1 aasta ja 8 kuud. Soome lapse kõne arengus on täheldatud sarnaseid tendentse: uuritav kasutas 2- ja 3sõnalisi ütlusi vanuses 1 aasta ja 5 kuud (sukka jalkaan pane, ee sokki panen jalga), 1 aasta ja 6 kuu vanusena ühendas laps subjekti, predikaadi ja adverbiaali (talo tähen sopii, ee siia sobib maja) (Laalo, 2003). Ka Leiwo (1993) märgib, et oluline etapp grammatika arengus on subjekti, predikaadi ja objekti arenemine lause pealiikmeteks ning pealiikmete laiendite tekkimine, mille tulemusena muutuvad laused pikemaks ja keerulisemaks (4-5sõnaliseks). Arguse (1995) järgi hakkas laps vanuses 2 aastat ja 0 kuud produktiivselt kasutama juba koondlauset ning vanuses 2 aastat ja 3 kuud kuni 2 aastat ja 8 kuud liitlauset, sh ilmnes nende lausetüüpide puhul ühine seaduspära: esialgu ühendas või rinnastas laps lauseid ilma sidesõnadeta. 4aastased lapsed rakendavad erinevaid lihtlausete ja kindlasti ka juba liitlausete tüüpe (Leiwo, 1993). Kui 4aastaste laste kasutatavate väljendite keskmine pikkus on 5 morfeemi, peaks laste kõnes olema vähemalt $20 \%$ liitlauseid (Steffani, 2007). Huttenlocheri, Vasilyeva, Cymermani ja Levine’i (2002) uurimuse kohaselt on 4aastaste laste kõnes liitlausete osakaal 7-35\%.

Sisendkeele ja esimeste lausete kasutamise tulemusena kujunevad mälus süntaktilised skeemid, lausete etalonid, mille alusel moodustatakse sama tüüpi lauseid. Keerulisemate lausete kasutus on seotud kõne dekontekstualiseerumisega, sh vajadusega väljendada tegevuste-/sündmustevahelisi ajalisi ja põhjuslikke seoseid (Steffani, 2007). Kahesõnalise lause perioodil hakkavad põimuma süntaktilised ja morfoloogilised oskused. Morfoloogia omandamisel eristatakse kolme etappi (vt Argus, 2008; Bittner, Dressler, \& Kilani-Schoch, 2003; Dressler, 2005). Premorfoloogilisel perioodil kasutab laps sõnu algvormis ja piiratud hulgal terviküksustena omandatud sõnavorme. Ehkki juba sel etapil ilmnevad keeltevahelised erinevused, puudutavad need peamiselt markeerimata ja/või väga suure kasutussagedusega vorme, nagu ainsuse ja mitmuse nimetav (sõnad, mille puhul eelistatakse või kasutatakse ainult mitmust, nt juuksed), infinitiivid, käskiva kõneviisi ainsuse vormid, oleviku ainsuse 1. või 3. pöörde vormid (Dressler, 2005). Järgneb protomorfoloogiline periood, mil laps hakkab varem omandatud vormide põhjal tegema üldistusi ning konstrueerima analoogial põhinevaid moodustisi. Sel perioodil ilmnevad vormide moodustamisel ka vead, eelkõige üleüldistamine (vt allpool). Arguse (2004) sõnul ei lõpe premorfoloogiline periood järsku, ka protomorfoloogilisel perioodil on veel hulganisti lekseeme, millest laps kasutab ainult üht kindlat käändevormi. Viimaseks etapiks on üleminek täiskasvanupärasele morfoloogiale. Oluline on siinkohal märkida, et eelnimetatud etapid ei pruugi lapse kõne arengus 
selgelt eristuda. Bittner jt (2003) rõhutavad, et fleksiooni kvalitatiivsete muutustega paralleelselt muutub ka süntaks keerukamaks.

Deen (2012) teeb morfoloogiauuringute põhjal mõned olulised üldistused. Esiteks, morfoloogiliste kategooriate poolest rikastes keeltes (nt eesti, soome, türgi keeles) omandatakse sõnavormid varem kui vaese morfoloogiaga keeltes (nt inglise keeles). Selle põhjuseks on Dressleri (2005) järgi asjaolu, et morfoloogiliselt rikkas keeles täidab morfoloogia rohkem funktsioone, mis ilmnevad rohkemates vormi ja tähenduse vastendustes, ning seetõttu avastavad lapsed morfoloogilised seaduspärasused varem. Teiseks, regulaarsed moodustussüsteemid omandatakse varem kui ebaregulaarsed, sh tehakse vähem vigu omandamisprotsessis (vrd nt eesti keeles mitmuse osastava ja ainsuse alaleütleva moodustamine). Kolmandaks, keeles domineerivad morfeemide ärajätu vead (errors of omission), seevastu asendusvigu (errors of commission) on vähem. Mitmusevormides esineb tavaliselt rohkem vigu, sest ka sisendis on neid vorme vähem kui ainsuse omi. Eesti keeles võib nii käänd- kui ka pöördsõnade mitmuslike vormide moodustamisel esineda mõlemat tüüpi vigu. Neljandaks, laps on omandanud suurema osa morfoloogiast 5. eluaastaks või isegi varem, st ta kasutab vähemalt $80 \%$ juhtudest kohustuslikes kontekstides vorme õigesti.

Järgnevalt kirjeldatakse täpsemalt eesti laste morfoloogiliste oskuste arengut. Argus $(2004,2008)$ märgib, et verbimorfoloogia hakkab arenema mõnevõrra varem kui noomenimorfoloogia. Ta põhjendab seda asjaoluga, et verbi muutetunnuste järele tuntakse vajadust juba kahesõnalistes lausetes, ning verbilekseemide ja vormide suure sagedusega sisendkeeles (Argus, 2008). Juhtumiuuringute (Argus, 2007; Salo, 1994; Salasoo, 1995; Vihman \& Vija, 2006) põhjal saab järeldada, et eesti laste tegusõnavormide kasutus algab vanuses 1 aasta ja 7 kuud kuni 1 aasta ja 8 kuud sõnatüvede kasutusega: esimesed vormid on kas imperatiivi ainsuse 2. pöörde vormid (pane), oleviku eitus (ei oska) või lihtminevik ilma mineviku tunnuseta ( $k u k k u \rightarrow$ $k u k k u s$ ). Varakult ilmuvad kõnesse ka kõik oleviku ainsuse pöörded (sh ainsuse 3. pööre, mis on üks enim kasutatud vorme varases kõnes), da- ja mainfinitiiv, oleviku mitmuse 1. pööre (Argus, 2007; Vihman \& Vija, 2006). Analoogilised tendentsid avalduvad tegusõnavormide omandamisel soome laste kõnes. Laalo (2003) sõnul algab tegusõnavormide areng kahest baasvormist: imperatiivi ainsuse 2. pöördest ja oleviku ainsuse 3. pöördest. Nimetatud vormid esinevad kõnes varem kui eesti lastel - imperatiiv juba alates 10. elukuust ning oleviku ainsuse 3. pööre alates vanusest 1 aasta ja 4 kuud.

Vihman ja Vija (2006) toovad välja eesti laste verbimoodustuses esinevad vead: morfeemi ärajätt ehk verbitüve kasutus, morfofonoloogilised vead ehk tüve- või tunnusevariandi valiku raskused ning asendusvead ehk 
tähenduse väljendamisel sobimatu vormi kasutus. Üks uuritavatest, kes oli inglise-eesti kakskeelne laps, tegi palju morfeemi ärajätu- ja ka asendusvigu (saada $\rightarrow$ saama), samas kui ükskeelse uuritava kõnes domineerisid morfofonoloogilised vead: olevikutüve üleüldistamine lihtmineviku vormide moodustamisel (hoias $\rightarrow$ hoidis) ning $d a$-infinitiivi kasutusel (tegeda $\rightarrow$ teha).

Arguse (2007) arvates võib verbi(aja)vormide omandamise järjekorda mõjutada vormi morfoloogiline produktiivsus, markeerituse aste, kontekst (vormide omandamise seotus kindlat tüüpi situatsioonidega) ning leksikaalsemantilised tegurid. Võib oletada, et 3. eluaastaks on eesti lastel aktiivses kasutuses kõik oleviku ja lihtmineviku ning $m a$ - ja $d a$-infinitiivi vormid. Argus ja Parm (2010) aga väidavad, et 4. eluaastaks pole eesti lapsed veel ajakategooriat täielikult omandanud.

Laps hakkab käändsõnavorme aktiivselt omandama alles siis, kui väljendi keskmine pikkus on üle kolme sõna (Argus, 2008). Käändesüsteemi omandamist alustavad eesti ja soome lapsed nimetavakujulisest algvormist. Samas ei saa materjali vähese hulga tõttu väita, et käändevaba periood esineb kõikide laste kõnes (Argus, 2004; Laalo, 2009). Tervikvormina omandatud osastav ja lühike sisseütlev (poodi) tekkisid esimeste vormidena eesti ja soome laste kõnesse vanuses 1 aasta ja 6 kuud kuni 1 aasta ja 7 kuud, samal ajal ilmusid sinna ka kaasaütleva vormid (emmega) (Argus, 2004; Laalo, 2009). Esimeste vormide kasutust mõjutavad ilmselt morfosüntaktilised ja pragmaatilised tegurid, nende vormidega saavad lapsed väljendada oma vajadusi. Salo (1994) uuringus hakkas laps esimeste noomenisufiksitena kasutama 1 aasta ja 4 kuu vanuselt mitmuse tunnust (torud) ning 1 aasta ja 5 kuu vanuselt ainsuse lõputa osastavat (palli). Seevastu esimese vormina omandati hoopis omastav, mis Arguse (2004) järgi ilmus laste kõnesse grammatilistest käänetest kõige hiljem. Omastava tüvi muutus oluliseks alles adverbiaalsete käänete ning mitmusevormide omandamisel. Esimese väliskohakäändena ilmus kõnesse alaleütlev (mulle, emmele; lapse vanus 1 aasta ja $10 \mathrm{kuud}$ ), ning 2aastaselt kasutas laps seda juba produktiivselt. Esimesed väliskohakäändevormid olid kasutusel valdaja, mitte koha tähistamiseks. Mitmusevormid ilmusid kõnesse pisut hiljem kui ainsuse vormid: mitmuse nimetava ja osastava aktiivset kasutust on täheldatud juba enne lapse 2. eluaastat (Argus, 2004).

Argus (2004) kirjeldas ühe lapse kõne arengut vanuseni 2 aastat ja 8 kuud. Lapse ja täiskasvanu dialoogi lindistustes ei esinenud kordagi ilmaütleva ega oleva käände vorme. See viitab nende väiksele kasutussagedusele, mille mõju morfoloogia omandamisele on märkinud kõik artiklis viidatud uurijad (Argus, 2008; Dressler, 2005; Laalo, 2009 jt). 


\section{Kõne arengu hilistuse ehk peetusega lapsed}

Uuringute (Rice et al., 2008) kohaselt saab 24kuusel lapsel juba määrata kõne arengu hilistumist. 10-15\% selles vanuses lastest on sõnavara märksa väiksem kui tavapärase arenguga lastel ning nad ei kasuta suhtlemisel 2-3sõnalisi ütlusi, mida peetakse selles vanuses oluliseks arengutähiseks (Desmarais et al., 2008; Hawa \& Spanoudis, 2014). Selliseid lapsi nimetatakse teaduskirjanduses kõne arengu peetusega (KAP) lasteks ehk hiliskõnelejateks (ingl late talkers).

KAP lastele on iseloomulik ekspressiivse kõne arengu mahajäämus kahjustamata kuulmise, mitteverbaalse võimekuse ja isiksuse arengu korral. Seega on tegemist vaid ühe arenguvaldkonna - kõne - ebatüüpilise arenguga, mille aluseks peetakse keele omandamise võime nõrkust (Rescorla et al., 2000; Rescorla \& Turner, 2015). Kõne arengu hiline algus on seotud neurobioloogilise ja geneetilise mehhanismiga: üheks peamiseks riskifaktoriks kõnehilistumise tekkel on peres esinevad keelepuuded ja lugemis-kirjutamisraskused (Desmarais et al., 2008; Everitt et al., 2013; Hawa \& Spanoudis, 2014).

KAP laste kõneline mahajäämus ilmneb eri vanuses erinevates kõnevaldkondades: 2aastastel sõnavaras ja fonoloogias, 3-4aastastel morfoloogias, 5aastastel keerulises süntaksis. Just grammatikaoskuste omandamine on KAP laste jaoks keeruline (Rescorla, 2011; Rice et al., 2008). Kuna eakohase arenguga (EK) laste grammatika hakkab eri keeltes arenema 2. eluaastal (vt Dressler, 2005), siis piiratud sõnavara ja fonoloogia taustal on selge, et KAP lastel nende oskuste kujunemine hilineb. Ingliskeelsetes uurimustes esines KAP lastel EK lastega võrreldes mahajäämus süntaktilistes oskustes nii 3 kui ka 4 aasta vanuses (Rescorla et al., 2000; Rescorla \& Turner, 2015). Nad kasutasid spontaanses kõnes lühemaid ütlusi ning ka lihtsama struktuuriga lauseid. Everitti jt (2013) kohaselt tuleks 3-4aastastel lastel kindlasti hinnata põhjalikult süntaktilisi oskusi, kasutades selleks näiteks lausete järelekordamise võtet, mille tulemused võimaldavad hinnata kõnelist mahajäämust. Piiratud lauseloomeoskus mõjutab sõnavormide kasutust. Rescorla ja Roberts (2002), kes hindasid 3- ja 4aastaste KAP laste nimi- ja tegusõnavormide kasutamise oskust, leidsid, et mõlemas vanuserühmas olid KAP laste tulemused EK omadest nõrgemad, sh sarnanes 4aastaste KAP laste sooritus 3aastaste EK laste omaga. See kinnitab KAP laste morfoloogiliste oskuste hilinenud, kuid mitte kvalitatiivselt teistsugust arengut.

Rescorla ja Turneri (2015) uurimistulemuste kohaselt on 5aastaste KAP laste grammatiliste morfeemide kasutus sarnane EK laste omaga: uuritud 14 morfeemist vaid ühe (inglise keele kõnelejatele raske oleviku ainsuse 
3. pöörde) puhul esines kahe rühma tulemuste vahel oluline erinevus. Mõlemad lasterühmad tegid morfeemide kasutamisel ka sarnaseid vigu: enim jäeti morfeeme ära, harvem asendati üks morfeem teisega (nt oleviku ainsuse 3. pööre asendati mitmuse 3. pöördega) ja lisati morfeem sinna, kus seda pole vaja (ibid.). Rice'i jt (2008) uuringust aga selgus, et mõnedel KAP lastel esineb mahajäämust morfosüntaktilistes oskustes, eriti ajavormide kasutuses, veel 7aastaselt. Inglise keelt kõnelevatel KAP ja EK lastel on verbimorfoloogiat keerulisem omandada kui nimisõnamorfoloogiat. See kinnitab taas, et KAP laste areng on sarnane EK laste omaga, ainult hilisem (Rescorla \& Roberts, 2002; Rescorla \& Turner, 2015). KAP lastel ilmnevad raskused just nende kategooriate omandamisel, mis on keeles rasked. Eri keeltes ei ole see aga sarnane: kuigi inglise keele puhul on täheldatud, et verbimorfoloogia on nimisõnamorfoloogiast keerulisem, pole see nii kõikides keeltes. Rikka fleksioonimorfoloogiaga keeltes, nagu näiteks hispaania ja ungari keel, ei ole verbimorfoloogia omandamine kõnelise mahajäämusega laste jaoks nii raske (Lukács et al., 2010).

Uuringud kinnitavad, et 70-80\% lastest, kes 2 aasta vanuses olid kõne arengu peetusega, saavutavad mingis vanuses standardiseeritud testides eakohased tulemused (Everitt et al., 2013; Hawa \& Spanoudis, 2014). Üldiselt peetakse selleks vanuseks 5 aastat (Paul \& Roth, 2011; Rescorla, 2011). Kõnehilistusega lapsed, kes 5aastaselt on kõne arengu näitajate poolest veel EK lastest märgatavalt nõrgemad, on tõenäoliselt juba raskema ja püsivama puudega - nn spetsiifilise kõnearengupuudega (vt Hallap, Padrik, \& Raudik, 2014; Padrik, 2014).

\section{Empiiriline uurimus}

\section{Eesmärk, uurimisülesanded ja hüpoteesid}

Uurimuse eesmärk on kirjeldada ja võrrelda eakohase ja hilistunud kõnearengu grammatilisi profiile ja leida tunnused, mille alusel on võimalik eristada kõne arengu poolest riskirühma kuuluvaid lapsi. Selleks püstitati järgmised ülesanded ja hüpoteesid.

1. Kirjeldada 3- ja 4aastaste laste lauseloomeoskusi. Lastekeele uurijad on eri keeltes valdavalt kirjeldanud 2-3aastaste laste süntaksi arengut. Eestis puuduvad andmed 3-4aastaste laste lauseloome arengu kohta, kuigi paljud selles vanuses lapsed hakkavad käima lasteaias ning sel ajal on vaja ja võimalik märgata arengulist mahajäämust. Eri keeltes tehtud uuringute (vt Huttenlocher et al., 2002; Leiwo, 1993; Steffani, 2007) alusel võib eeldada, et eesti keelt kõnelevad 4aastased lapsed kasutavad kõnes 
erinevaid liht- ja liitlauseid. 3aastaste kõnes avalduvad süntaksi varasele arengule omased tendentsid (Kapanen, 2014).

2. Kirjeldada 3- ja 4aastaste laste käände- ja pöördevormide kasutust. Deen (2012) väidab, et üldjuhul on laps omandanud suurema osa morfoloogiast 5. eluaastaks, morfoloogiliste vormide poolest rikastes keeltes isegi varem. Argus $(2004,2008)$ on leidnud, et eesti lastel hakkab verbimorfoloogia arenema mõnevõrra varem kui noomenimorfoloogia. Seega võib eeldada, et 4aastased EK lapsed on verbi- ja noomenimorfoloogia valdavalt omandanud, st kasutavad vähemalt $80 \%$ juhtudest vorme õigesti. 3aastased lapsed on jõudnud arengus protomorfoloogilisse perioodi, mil nad loovad analoogiamoodustisi ning seega eksivad sagedamini. Erinevalt $n$-ö vaese morfoloogiaga keeltest ei domineeri vigade hulgas morfeemi ärajätt, vaid lapsed eksivad ka tüve- ja lõpumorfeemide, sh nende variantide valikul (Hallap et al., 2014; Vihman \& Vija, 2006). Samuti otsitakse artiklis kinnitust seisukohale, et morfoloogiliste vormide ilmumist kõnesse mõjutavad vormi esinemissagedus sisendkeeles ja semantilised tegurid (vormi roll, tähendus) (Argus, 2008), mistõttu eristuvad vormid, mida kasutavad nii 3- kui ka 4aastased lapsed kas edukamalt või vähem edukalt.

3. Analüüsida KAP laste morfosüntaktilisi oskusi ja võrrelda neid eakaaslaste oskuste profiiliga. Tuginedes varasematele uuringutele (Rescorla et al., 2000; Rescorla \& Roberts, 2002; Rescorla \& Turner, 2015), võib oletada, et KAP laste kõne morfosüntaktiline areng on eakaaslastest oluliselt maha jäänud, kuid oskuste profiil on sama: rohkem eksitakse samade, st raskeimate keelendite kasutuses. Keeleliste oskuste kvalitatiivselt sarnast arengut kinnitavad KAP laste vead, mis tüübilt sarnanevad EK laste omadega. Sarnasus on suurem nooremate, st 3aastaste EK lastega.

4. Selgitada välja tunnused, mille alusel on võimalik märgata eesti laste kõne arengu hilistumist vanuses 3-4 aastat. Inglise keeles tehtud uuringutele toetudes võib oletada, et KAP lapsed kasutavad eakaaslastega võrreldes lühemaid ning lihtsama struktuuriga lauseid (Rescorla et al., 2000; Rescorla \& Turner, 2015). Arenguline mahajäämus avaldub eriti selgesti lausete järelekordamisel (Everitt et al., 2013). Arvestades, et keele omandamist mõjutab keelespetsiffika (vt Argus, 2008; Bittner et al., 2003; Dressler, 2005; Lukács et al., 2010), võib eeldada, et eesti KAP lastel avalduvad raskused mitte ainult verbi-, vaid ka noomenimorfoloogia omandamisel. 


\section{Metoodika}

\section{Valim}

Valimi moodustasid 335 3-4aastast EK ja 61 KAP last (kontrollrühm) (vt tabel 1). EK lastest 149 olid 3aastased (44\%) ja 186 4aastased (56\%). Arvestades kõne kiiret arengut 3. eluaastal, oli noorema vanuserühma puhul vanusevahemik piiritletud kitsamalt kui vanematel lastel, et saavutada rühma suurem homogeensus. KAP rühm on sobitatud vanuseliselt EK laste rühmaga: 27 last (44\%) vastasid EK3 ja 34 (56\%) EK4 rühma vanusele. Soo alusel jagunesid EK laste rühmad proportsionaalselt peaaegu võrdselt. KAP laste rühmas moodustasid enamuse poisid, mis vastab soolisele jaotusele keelepuuetega laste seas (Zambrana, Ystrom, \& Pons, 2012).

Laste kõne arengu hindamisel toetuti logopeedide ja lasteaiaõpetajate eksperdihinnangutele. EK lapsed ei vajanud logopeedilist abi. Kontrollrühma puhul oli logopeed fikseerinud kõne arengu mahajäämuse, mis ei tulenenud ühestki esmasest puudest (nt kuulmis-, liikumis- või intellektipuue, autismispektrihäire): lapse arenguloos puudusid kõne- või tunnetustegevuse arengut mõjutavad meditsiinilised diagnoosid. Uuringu hetkel kasutasid lapsed peamise suhtlemisviisina kõnet, st tegemist ei olnud alakõne esimesel astmel (vt Padrik, 2014) olevate kõnetute lastega.

Kõik valimisse kuulunud lapsed käisid lasteaias ja olid pärit ükskeelsetest peredest. Lasteaedade valikul arvestati nende piirkondlikku paiknemist ja asukohta (maa- ja linnalasteaiad): andmeid koguti Harju-, Tartu-, Lääne-, Võru-, Jõgeva- ja Pärnumaalt ning Ida- ja Lääne-Virumaalt. 2/3 lastest käis lasteaias linnas, 1/3 maal.

Tabel 1. Lasterühmade vanuseline ja sooline jaotumus

\begin{tabular}{l|c|c|c}
\hline Lasterühm & EK3 & EK4 & KAP \\
\hline Laste arv & 149 & 186 & 61 \\
\hline Vanusevahemik aastates ja kuudes & 2 a $11 \mathrm{k}-3$ a $5 \mathrm{k}$ & 3 a $6 \mathrm{k}-4$ a $5 \mathrm{k}$ & 2 a $11 \mathrm{k}-4$ a $5 \mathrm{k}$ \\
\hline Sooline jaotumus & $\mathrm{N}=75(50 \%)$ & $\mathrm{N}=87(47 \%)$ & $\mathrm{N}=17(28 \%)$ \\
& $\mathrm{M}=74(50 \%)$ & $\mathrm{M}=99(53 \%)$ & $\mathrm{M}=44(72 \%)$ \\
\hline
\end{tabular}

\section{Mõõtevahendid ja protseduur}

Mõõtevahendiks on aastatel 2014-2016 ellu viidava projekti „Vahendite loomine ja kohandamine eelkooliealiste laste arengu hindamiseks" raames välja töötatava 3-4aastaste laste kõne hindamise testi ülesanded, millega 
hinnatakse grammatika arengut (ülesanded on koostanud artikli autorid). Testi aluseks on võetud Euroopa kultuuriruumis kasutatavad standardiseeritud kõnetestid, nt Reynelli test (Letts, Edwards, Schaefer, \& Sinka, 2014), Heidelberger Sprachentwicklungstest (HSET) (Grimm \& Schöler, 1991), Kettu test (Korpilahti \& Eilomaa, 2012) ja varasemad uuringud eesti lapse keelelise arengu kohta (Argus, 2008; Hallap et al., 2014).

Andmekogumismeetodina kasutati grammatiliste vormide kasutuse ning lauseloome suunatud esilekutsumist (ingl structured elicitation method), mis võimaldab spontaanse kõne hindamisega võrreldes uurida laste grammatilisi oskusi eesmärgipärasemalt ja ajaliselt ökonoomsemalt. Lauseloomeoskuse uurimisel kasutati lisaks esilekutsutud järelekordamise meetodit (ingl elicited imitation method), mis on suunatud esilekutsumisega võrreldes lapsele lihtsam (ei eelda lause semantilist kavandamist), kuid võimaldab uurida nii keelelise info töötlust kui ka olemasolevaid keelelisi teadmisi. Sel viisil on võimalik uurida ka spontaanses kõnes harva kasutatavate lausemallide omandatust (Polišenská, Chiat, \& Roy, 2015; Riches, 2012). Mõõtevahendit ja vastuste kodeerimise süsteemi katsetati kaks korda (2014. aasta sügisel ja 2015. aasta kevadel), mille tulemusena täpsustati ja parandati keelematerjali valikut, kodeerimissüsteemi ja pildimaterjali kvaliteeti.

Lauseloomeoskuse uurimine. Esimeses ülesandes uuriti lapse oskust moodustada lauseid ${ }^{2}$ uurija tegevuse alusel. Uurija tegutses mänguasjadega ja palus lapsel nähtut kommenteerida. Ülesandele eelnes kaks näidet: Vaata! (uurija näitab, kuidas konn hüppab); Konn hüppab. Räägi sina ka konna kohta! (laps: Konn hüppab). Kui laps ei rääkinud, kordas uurija ise lauset. Uuringu käigus uurija ise oma tegevust ei kommenteerinud, kuid kordas alati üle lapse moodustatud õige lause või täiendas/parandas mitte-eeldatud lauset, andes sel viisil näite, kuidas kommenteerida nähtud tegevust. Lapsele esitati kaheksa tegevusolukorda ja eeldati, et ta moodustab kuus baaslauset (st elementaarlauset, vt Rätsep, 1978), mis sisaldavad peale verbi ainult obligatoorseid laiendeid (alust, sihitist või määrust, kaks lauset nii sihitist kui ka määrust). Määrustest eeldati koha-, vahendi- ja valdajamääruse kasutamist. Kaks lauset sisaldasid peale obligatoorsete ka ühte fakultatiivset laiendit (vt tabel 3). Vahenditeks olid väikesed mänguasjad: konn, auto, kaks näpunukku (jänesed), lennuk, klotsid, pliiats, karp.

Teise ülesandega uuriti lapse oskust korrata järele kaheksat lausemalli (kolme baaslauset, nt Mina oskan hüpata; üht fakultatiivse laiendiga

Artiklis kasutatakse uurimuse eesmärgist tulenevalt terminit lause ka suulises kõnes esineva lause ehk lausungi tähistamiseks. 
lihtlauset, nt Mulle meeldib rattaga sõita; sihitis- ja ajapõimlauset, nt $\mathrm{Ma}$ jooksen ära, kui karu tuleb; ühendava sidendiga rind- ja koondlauset, nt Mina söön saia ja joon piima). Motiveerimiseks kasutati näpunukku, mille kaudu esitati stiimullaused. Ülesandele eelnes kaks näidet, nt Kuula, mida Juss ütleb! Minul on saba. Ütle sina ka! Kui laps ei korranud, esitati näide ja suunav korraldus uuesti.

Morfoloogia uurimine. Lapsel tuli vastata uurija esitatud küsimusele ja/ või lõpetada lause eeldatud sõnavormiga, toetudes piltidele. Tegusõnavormide kasutuse esilekutsumiseks pidid nii uurija kui ka laps ka tegevust imiteerima. Katsevahendina kasutati kaheksat A5 vormingus värvilist pilti, mis kujutasid jäneste Juta ja Jussi päeva. Piltidele toetudes lõi uurija lapsele raamjutustuse, mille kaudu ta vestles lapsega. Näiteks oli esimese pildi puhul uuringu käik järgmine.

Uurija: Vaatame nüüd pilte. Jänkud ärkasid hommikul üles ja läksid vannituppa. Pildil: vannituba, Juss kuivatab kraanikausi juures käsi. Uurija: Mida Juss teeb? (Kuivatab käsi.) Millega Juss käsi kuivatab? (Rätikuga.) Uurija võtab pildi lapse eest ära ja nihutab tema ette mängukonna. Ütle konnale ka, mida Juss tegi. Abistamiseks alustab uurija lauset: Juss ... (Kuivatas käsi.) Uurija imiteerib käte kuivatamist. Vaata, mina ka kuivatan nü̈̈d mängult käsi. Nü̈̈d lõpetasin! Ütle konnale ka, mida ma tegin! (Kuivatasid käsi.)

Ülesandes pidi laps kasutama nimetavat mitmuses ja osastavat nii ainsuses kui ka mitmuses (hulgasõna laiendi funktsioonis), lisaks tuli ainsuse käändevormidest kasutada seestütlevat (selle objekti funktsioonis, millele on tegevus suunatud), alale- ja alaltütlevat (vastavalt adressaadi ja lähteallika funktsioonis), ilma- ja kaasaütlevat. Tegusõnavormidest uuriti kõiki oleviku ja lihtmineviku aktiivivorme nii ainsuses kui ka mitmuses (v.a mitmuse 2. pööre). Samuti uuriti $d a$-infinitiivi kasutamise oskust. Igat vormi pidi laps kasutama 2-3 korda.

Vormimoodustust uuriti 13 nimi-, 2 omadus- ja 8 tegusõna puhul. Sõnade valikul lähtuti järgmistest põhimõtetest: 1) tuttavus lapsele, 2) esinemissagedus, 3) silbistruktuur, 4) sõnatüve astmevahelduslikkus, 5) kujutatavus pildil. Ülesanne sisaldas lapsele igapäevaelust tuttavaid suurema ja väiksema kasutussagedusega nii lühemaid (1-2silbilisi) kui ka pikemaid (3-4silbilisi) laadivahelduseta sõnu proportsionaalselt.

Andmeid koguti veebruarist detsembrini 2015. Katse tehti iga lapsega individuaalselt ruumis, kus viibisid ainult uuritav ja uurija. Ühe lapse testimine kestis keskmiselt 30 minutit. Ülesannete esitamise järjekord oli kõigi laste puhul sama. Lauseloomeülesannete tulemused salvestati diktofoniga 
ja transkribeeriti. Laste vastused kodeeriti kodeerimisjuhendi alusel. Et määrata kindlaks hindajatevaheline reliaablus kodeerimisel, hindasid kaks hindajat (erikoolituse läbinud magistriüliõpilane ja artikli esimene või teine autor) veerandit kõigist protokollidest. Kui hinnangutes oli erinevus, saavutati kokkulepe. Erinevused esinesid peamiselt lauseloomeülesannete kodeerimisel. 10\% juhuslikult valitud protokolli puhul hindasid lauseloomeülesannete kodeerimist kaks artikli autorit. Hindajatevaheline reliaablus oli $89 \%$.

\section{Andmeanalüïs}

Esimeses lauseloomeülesandes jaotati vastused kodeerimisel järgmiselt. Õigeks loeti vastused, kus laps oli kõiki olulisi tegevuse komponente väljendanud ühe lausega, lubatud oli suulisele kõnele omane sõnajärg (Lennukiga lendavad jänkud). Osaliselt õigeks (olukorda sobivaks) loeti laused, milles oli ära jäetud fakultatiivne või obligatoorne laiend (nt Konn sõidab $\rightarrow$ Konn sõidab autoga), ühe lauseliikme asemel oli kasutatud asesõna (nt Tema sõidab autoga) või üks laienditest oli nimetatud eraldi (suulises kõnes eristus pausiga) ja teine laiend oli ühendatud verbiga (nt Konn. Sõidab autoga). Seega andis laps tähenduse edasi mitme lausega. Mitte-eeldatud vastuste puhul nimetas laps tajutavaid objekte, kirjeldas olukorda ebaadekvaatselt (nt Konn oli siin. Jänku oli siin $\rightarrow$ Konn andis pliiatsi jänkule) või oli tema vastus väga situatiivne, st ta kasutas mitme lauseliikme asemel asesõnu, jättis ära obligatoorse lauseliikme (Teevad asju $\rightarrow$ Jänkud ehitavad torni). Siia rühma liigitati ka lõpumorfeemi või tagasõna kasutuse vigu sisaldavad laused (nt Hüppas klotsi jänku $\rightarrow$ Jänku hüppas klotsi peale) ja vastusest keeldumine.

Teises lauseloomeülesandes jaotati vastused õigeteks ja osaliselt õigeteks (laps jättis sõnu ära või asendas neid teistega, kuid ta kasutas siiski grammatiliselt õiget eeldatud lausemalli (nt Mina söön saia ja joon $\rightarrow$ Mina söön saia ja joon piima; Jussil on saba $\rightarrow$ Minul on saba). Valeks loeti lihtsustamine (ühe või mitme lihtsama lausemalli kasutamine eeldatu asemel), elliptilisus (obligatoorsete või fakultatiivsete laiendite ärajätmine, nt Emme annab $\rightarrow$ Emme annab jänkule kapsast), agrammatilised laused (nt Oska hüpata $\rightarrow$ Mina oskan hüpata) või sisult valed laused (nt Mina hüppan konnaga $\rightarrow$ Mina söön saia ja joon piima). Mõlemas ülesandes esines valede vastuste kombinatsioone. Vastuste rühmitamisel arvestati ka ülesande tüüpi, näiteks loeti esimeses ülesandes osaliselt õigeks ühe laiendi ärajätmine, mis on suulisele kõnele tegevusolukorras tüüpiline, seevastu järelekordamisel loeti sellised vastused elliptilisteks, sest ülesande püstitus 
oli teistsugune (last õpetati esmalt lauset järele kordama) ja lauseliikmete ärajätmine muutis lausemalli, mille valdamist sooviti hinnata.

Morfoloogia uurimisel jaotati vastused järgmiselt: õige vorm eeldatud sõnast; osaliselt õige vastus, st õige vorm mitte-eeldatud, kuid konteksti sobivast sõnast (nt ase- või uudissõnast), tüve- või lõpuvariandiveaga või sõna kuju muutva hääldusveaga vormid (nt korjastad $\rightarrow$ korjad). Valeks loeti lõpumorfeemi ärajätt, asendamine (nt ainsuse vorm mitmuse asemel), lisamine.

Andmeid töödeldi programmiga IBM SPSS Statistics 21.0. Esmalt arvutati iga ülesande piires eri tüüpi vastuste summaskoorid. EK3 ja EK4 ning EK ja KAP laste vastusetüüpide aritmeetilisi keskmisi võrreldi sõltumatute valimite $t$-testiga. Seejärel võrreldi laste tulemusi osaülesannete ja vastusetüüpide kaupa protsentides, sest ülesanded erinesid osaülesannete arvu poolest, seega ei olnud võimalik kasutada võrdlust keskmiste alusel. Samade laste sooritust eri ülesannete puhul võrreldi sõltuvate valimite $t$-testi abil. Et leida seoseid morfoloogia- ja lauseloomeülesannete tulemuste vahel, kasutati Pearsoni korrelatsiooni, sest tegemist oli pidevate arvtunnustega.

\section{Tulemused}

\section{3-4aastaste laste lauseloomeoskused}

Lauseloomeoskuste kirjeldamiseks analüüsiti laste vastuseid kahes ülesandes esmalt lausemallide ja seejärel vastusetüüpide kaupa. Kirjeldades uurija tegevust (edaspidi ülesanne LL1), kasutasid EK3 lapsed õigeid ja osaliselt õigeid lausemalle umbes pooltel juhtudest (õigeid 22\%), EK4 lapsed umbes kolmveerandil juhtudest (õigeid 45\%) (vt tabel 2). Erinevus vanuserühmade tulemuste vahel oli oluline: $t(319,46)=-7,92, p<0,01, d=0,87$. Kõige lihtsamateks lausemallideks osutusid mõlemale rühmale lausemallid 1, 2 ja 5, mis sisaldasid pealiikmetele lisaks vaid vahendi- või kohamäärust (vt tabel 3). 3aastaste jaoks olid raskeimad laused, kus peale pealiikmete oli vaja kasutada ka sihitist ja valdajamäärust (6. lause) või sihitist ja kohamäärust (8. lause), st mitut laiendit. Kuid lastele ei avaldanud mõju ainult lausemall, vaid ka uurija tegevuse tõlgendamine, mis oli 3aastastele raske 3. ja 4. lause puhul (õigeid alla 50\%). 4aastastele valmistas olukorra mõistmine vähem raskusi, kuigi ka nemad kirjeldasid uurija tegevust ebaadekvaatselt just 3., 4. ja 6. lause puhul (nt Konn pani jänku peitu $\rightarrow$ Konn andis pliiatsi jänkule). 
Tabel 2. Vastusetüübid lause moodustamisel uurija tegevuse alusel (\%)

\begin{tabular}{l|c|c|c|c}
\hline Vastusetüüp & $\begin{array}{c}\text { EK3 } \\
(N=149)\end{array}$ & $\begin{array}{c}\text { EK4 } \\
(N=186)\end{array}$ & $\begin{array}{c}\text { EK3-4 } \\
(N=335)\end{array}$ & $\begin{array}{c}\text { KAP } \\
(N=61)\end{array}$ \\
\hline Õige & 22,06 & 45,09 & 34,91 & 10,02 \\
\hline \multicolumn{5}{|l|}{ Osaliselt õige } \\
\hline Fakultatiivne laiend puudub & 6,88 & 5,98 & 6,72 & 3,79 \\
\hline Mitu lauset & 2,77 & 1,55 & 2,09 & 4,71 \\
\hline Alus puudub & 13,59 & 14,25 & 13,96 & 9,22 \\
\hline Asesõna & 7,47 & 5,58 & 6,42 & 3,69 \\
\hline Kokku (õige + osaliselt õige) & 52,77 & 72,45 & 64,10 & 31,43 \\
\hline Mitte-eeldatud vastus & \multicolumn{5}{|l}{} \\
\hline Situatiivne lause & 13,76 & 8,47 & 10,82 & 16,16 \\
\hline Nimetamine & 10,15 & 6,38 & 8,06 & 14,96 \\
\hline Ebaadekvaatne kirjeldus & 12,64 & 5,58 & 8,51 & 11,89 \\
\hline Tagasõna puudub/vale & 1,09 & 0,54 & 0,78 & 1,64 \\
\hline Agrammatism & 5,12 & 3,63 & 4,29 & 8,40 \\
\hline Kombinatsioon & 0,17 & 0,13 & 0,15 & 6,15 \\
\hline Kokku (mitte-eeldatud) & 43,71 & 25,40 & 33,14 & 59,14 \\
\hline Vastamata & 3,52 & 2,15 & 2,76 & 9,43 \\
\hline Markus, Protsentide & & & \\
\hline
\end{tabular}

Märkus. Protsentide arvutamisel on EK3 puhul lähtutud 1192, EK4 puhul 1488, EK puhul kokku 2680 ja KAP puhul 488 vastusest.

Tabel 3. Lasterühmade tulemused lause moodustamisel tegevuse alusel (\%)

\begin{tabular}{l|c|c|c|c}
\hline Ülesanne & $\begin{array}{c}\text { EK3 } \\
(N=149)\end{array}$ & $\begin{array}{c}\text { EK4 } \\
(N=186)\end{array}$ & $\begin{array}{c}\text { EK3-4 } \\
(N=335)\end{array}$ & $\begin{array}{c}\text { KAP } \\
(N=61)\end{array}$ \\
\hline 1. Konn sõidab autoga & $80,5(32,2)$ & $89,8(28,5)$ & $85,6(30,1)$ & $60,6(26,2)$ \\
\hline 2. Jänkud lendavad lennukiga & $61,1(36,9)$ & $74,8(28,0)$ & $68,6(31,9)$ & $32,8(26,2)$ \\
\hline 3. Jänkud ehitavad torni & $49,0(38,3)$ & $65,0(33,3)$ & $57,9(35,5)$ & $24,6(18,0)$ \\
\hline 4. Konn läks auto taha & $46,3(25,5)$ & $63,5(21,0)$ & $55,8(23,0)$ & $19,7(14,8)$ \\
\hline 5. Jänku läks klotsi peale & $61,0(34,2)$ & $79,4(26,9)$ & $71,0(30,1)$ & $36,1(21,3)$ \\
\hline 6. Konn andis pliiatsi jänkule & $41,0(24,2)$ & $63,9(22,0)$ & $53,7(23,0)$ & $32,8(26,2)$ \\
\hline 7. Konn ja jänes läksid karbi sisse & $49,7(33,6)$ & $76,3(36,0)$ & $64,5(34,9)$ & $26,2(21,3)$ \\
\hline 8. Jänku pani klotsi karbi sisse & $43,0(30,2)$ & $72,1(28,0)$ & $59,1(29,0)$ & $26,2(21,3)$ \\
\hline
\end{tabular}

Märkus. Õigete ja osaliselt õigete vastuste osakaal vastustest (sulgudes osaliselt õigete vastuste protsent). 
3- ja 4aastaste laste vastusetüübid (vt tabel 2) olid suhteliselt sarnased: olukorda kirjeldades ei nimetanud nad tegijat (alus puudus) või kasutasid ühe lauseliikme asemel asesõna, mis oli tingitud jagatud kontekstist. Kõne situatiivsus oli aga oluliselt suurem 3 aastastel lastel, kes jätsid ära obligatoorseid lauseliikmeid ja liialdasid asesõnadega sagedamini kui 4aastased (väljaspool tegevusolukorda mittemõistetavaid lauseid: $t(271,42)=3,63$, $p<0,01, d=0,40)$. Samuti kirjeldasid 3aastased olukorda sagedamini ebaadekvaatselt: $t(236,94)=3,85, p<0,01, d=0,42$ (nt Konn käib vette $\rightarrow$ Konn läks auto taha).

Järelekordamisel (LL2, vt tabel 4) moodustasid lapsed õigeid ja osaliselt õigeid lausemalle oluliselt rohkem kui LL1s (EK3 puhul erinevus kahes ülesandes $t(148)=-4,27, p<0,01, d=0,37$; EK4 $t(185)=-7,41, p<0,01$, $d=0,55)$. Lihtsamateks osutusid baas- ja lihtlaused (õigeid 72-83\%), mille hulgas oli kolme obligatoorset laiendit sisaldav 3. lause (Emme annab jänkule kapsast) mõnevõrra raskem kui 1. lause (Mina oskan hüpata). Raskemate lausemallide hulka kuulusid sihitis- ja ajapõimlause, rind- ja koondlause (õigeid 41-58\%). EK4 lastele osutus eri tüüpi lausemallide järelekordamine igati jõukohaseks. Raskeimad olid põimlaused. 3- ja 4aastaste laste tulemused lausete järelekordamisel erinesid oluliselt nii õigete vastuste poolest $(t(289,61)=-7,76, p<0,01, d=0,85)$ kui ka valede vastuste tüüpide poolest (vt tabel 5). 3aastased kasutasid lihtsamaid lausemalle ja elliptilisi lauseid oluliselt sagedamini kui 4aastased (vastavalt $t(237,5)=$ $5,01, p<0,01, d=0,55 ; t(158,15)=3,63, p<0,01, d=0,40)$. Samuti jätsid nad sagedamini vastamata.

Tabel 4. Lasterühmade tulemused järelekordamise ülesandes (\%)

\begin{tabular}{l|c|c|c|c}
\hline Ülesanne & $\begin{array}{c}\text { EK3 } \\
(N=149)\end{array}$ & $\begin{array}{c}\text { EK4 } \\
(N=186)\end{array}$ & $\begin{array}{c}\text { EK3-4 } \\
(N=335)\end{array}$ & $\begin{array}{c}\text { KAP } \\
(N=61)\end{array}$ \\
\hline 1. Baaslause & $82,6(9,4)$ & $94,6(4,8)$ & $89,3(6,9)$ & $52,5(6,6)$ \\
\hline 2. Baaslause & $78,5(8,7)$ & $83,0(7,5)$ & $86,6(8,1)$ & $31,2(8,2)$ \\
\hline 3. Baaslause & $71,8(10,1)$ & $88,7(8,1)$ & $81,2(9,0)$ & $24,6(8,2)$ \\
\hline 4. Lihtlause (1 fakultatiivne laiend) & $77,2(3,4)$ & $92,5(2,7)$ & $85,7(3,0)$ & $29,1(4,9)$ \\
\hline 5. Koondlause & $51,7(13,4)$ & $87,1(8,1)$ & $71,3(10,4)$ & $18,0(8,2)$ \\
\hline 6. Rindlause & $56,4(22,8)$ & $87,1(21,5)$ & $73,4(22,1)$ & $29,5(16,4)$ \\
\hline 7. Ajapõimlause & $57,7(15,4)$ & $79,0(8,6)$ & $69,5(11,6)$ & $13,1(3,3)$ \\
\hline 8. Sihitispõimlause & $40,9(1,3)$ & $75,8(5,9)$ & $60,3(3,9)$ & $9,8(1,6)$ \\
\hline
\end{tabular}

Märkus. Õigete ja osaliselt õigete vastuste osakaal vastustest (sulgudes osaliselt õigete vastuste protsent). 
Tabel 5. Vastusetüüpide osakaalud lause järelekordamisel (\%)

\begin{tabular}{l|c|c|c|c}
\hline Vastusetüüp & $\begin{array}{c}\text { EK3 } \\
(N=149)\end{array}$ & $\begin{array}{c}\text { EK4 } \\
(N=186)\end{array}$ & $\begin{array}{c}\text { EK3-4 } \\
(N=335)\end{array}$ & $\begin{array}{c}\text { KAP } \\
(N=61)\end{array}$ \\
\hline Õige & 54,03 & 78,83 & 67,80 & 19,06 \\
\hline Osaliselt õige & 10,57 & 8,40 & 9,37 & 7,17 \\
\hline \multicolumn{5}{|l|}{ Vale vastus } \\
\hline Lihtsustamine & 9,06 & 3,76 & 6,12 & 7,38 \\
\hline Elliptilisus & 12,33 & 2,82 & 7,05 & 21,52 \\
\hline Agrammatism & 3,61 & 2,42 & 2,95 & 19,26 \\
\hline Sisult vale lause & 3,02 & 2,42 & 2,69 & 4,71 \\
\hline Vastamata & 6,88 & 1,08 & 3,66 & 10,86 \\
\hline Kombinatsioon & 0,25 & 0,20 & 0,22 & 10,04 \\
\hline
\end{tabular}

Märkus. Protsentide arvutamisel on EK3 puhul lähtutud 1192, EK4 puhul 1488, EK puhul kokku 2680 ja KAP puhul 488 vastusest.

\section{3- ja 4aastaste laste morfoloogilised oskused}

EK laste lauseloome- ja vormikasutusoskuste vahel ilmnes keskmise tugevusega positiivne seos (EK3 $-r=0,47$; EK4 $-r=0,51, p<0,01$ ). Vormikasutuse tulemuste analüüs näitas, et EK4 lapsed kasutasid nii käändekui ka pöördevorme edukalt (vt tabel 6, joonis 1). Erandlikult osutusid rasketeks ainsuse ilmaütlev (vaid pooled vastustest olid õiged) ja mitmuse osastav (lõpumorfeemi variandi vigu arvestamata oli õigeid vastuseid 67\%). Teiste pöördevormidega võrreldes mõnevõrra rohkem eksiti lihtmineviku ainsuse 2. pöörde ja mitmuse 3. pöörde korral (õigeid vastuseid vastavalt $74 \%$ ja $80 \%)$. Erinevus käände- ja pöördevormide kasutuses ei olnud EK4 puhul statistiliselt oluline $(t(185)=-1,26, p=0,21)$.

EK3 laste tulemused olid EK4 omadega võrreldes oluliselt halvemad (käändevormides $t(312,84)=-6,85, p<0,01, d=0,75$; pöördevormides $t(274,59)=-5,78, p<0,01, d=0,64)$, samuti vastasid nad sagedamini osaliselt õigesti, st eksisid rohkem tüve- ja lópuvariantide kasutuses ning moodustasid vorme mitte-eeldatud sõnadest. Käändevormidest olid ka EK3le rasked ilmaütlev (eeldatud vorm vaid 25\% juhtudest) ja mitmuse osastav (õigeid vorme 46\%). Mõnevõrra rohkem valmistas raskusi ka seestütleva käände kasutamine objekti puhul, millele on tegevus suunatud (õigeid vorme $77 \%$ ). Kõige vähem eksimusi esines alaleütleva ja ainsuse osastava käände vormide kasutamises (õigeid vorme ligi 95\%), kus tulemused olid sarnased EK4 omadega. Tegusõnavormide puhul valmistasid 3aastastele 
rohkem raskusi minevikuvormid (v.a mineviku ainsuse 3. pööre), samuti oleviku mitmuse 1. pöörde vormid (edukus 65-69\%). Siiski moodustasid EK3 lapsed tegusõnavorme oluliselt paremini kui käändsõnavorme $(t(148)=-2,57, p<0,01, d=0,21)$.

Tabel 6. Lasterühmade tulemused grammatiliste vormide kasutamisel (\%)

\begin{tabular}{l|c|c|c|c}
\hline Vastusetüüp & $\begin{array}{c}\text { EK3 } \\
(N=149)\end{array}$ & $\begin{array}{c}\text { EK4 } \\
(N=186)\end{array}$ & $\begin{array}{c}\text { EK3-4 } \\
(N=335)\end{array}$ & $\begin{array}{c}\text { KAP } \\
(N=61)\end{array}$ \\
\hline \multicolumn{5}{|l}{ Käändsõnavormid (kokku 23 vormi) } \\
\hline Õged & 66,47 & 78,54 & 73,17 & 33,78 \\
\hline Osaliselt õiged & 6,36 & 4,96 & 5,58 & 6,70 \\
\hline Valed & 27,17 & 16,5 & 21,25 & 59,52 \\
\hline Tegusõnavormid (kokku 23 vormi) & 67,45 & 80,40 & 74,64 & 35,92 \\
\hline Õiged & 8,24 & 6,28 & 7,15 & 11,40 \\
\hline Osaliselt õiged & 24,31 & 13,32 & 18,21 & 52,68 \\
\hline Valed &
\end{tabular}

\section{KAP laste lauseloomeoskused}

KAP laste tulemused olid EK laste omadest oluliselt halvemad mõlemas lauseloomeülesandes: LL1 $t(153,97)=9,42, p<0,01, d=1,31$, LL2 $t(93,58)=12,97, p<0,01, d=1,81$. LL1 (vt tabelid 2 ja 3 ) osutus KAP lastele üle jõu käivaks ülesandeks: olukorda sobivaid lauseid kasutati ligikaudu kolmandikul juhtudest (sh õigeid 10\%). Tervikliku, kõiki obligatoorseid laiendeid sisaldava lause moodustamine valmistas probleeme kõigi osaülesannete korral, teistest eristusid 1. ülesanne kui lihtsaim ja 4. ülesanne kui raskeim. KAP laste vastused olid valdavalt väga situatiivsed (16\%; erineus EKst ei olnud oluline) või pigem nimetati objekte ja tegevusi lauset moodustamata $(15 \% v s .8 \% \mathrm{EK} ; t(70,41)=-2,35, p<0,05$, $d=0,33) .12 \%$ juhtudest kirjeldasid KAP lapsed olukorda ebaadekvaatselt, kuid sedasama tegid võrdväärses mahus ka EK3 lapsed. EKst sagedamini jäeti vastamata $(t(64,95)=-2,51, p<0,05, d=0,35)$ või anti agrammatiline vastus $(t(68,36)=-2,42, p<0,05, d=0,34)$. KAP lastele oli iseloomulik ka vigade kombineerumine samas lauses (nt agrammatism + situatiivne lause, nt Anna pliiatsi $\rightarrow$ Konn andis pliiatsi jänkule; $t(60,17)=-3,07, p<0,01$, $d=0,43$.

Erinevalt EK lastest ei olnud lausete järelekordamine KAP lastele iseseisvast lauseloomest lihtsam (vrd tabelid 3 ja 4), seejuures oli tulemuste 
erinevus statistiliselt piiripealne $(t(60)=1,97, p=0,05, d=0,25)$. Lihtsaimaks osutus 1. lause (Mina oskan hüpata; õigeid 53\%), samas põimlauseid suudeti korrata vaid umbes $10 \%$ ja koondlauset $18 \%$ juhtudest. Liht- ja rindlausete järelekordamine õnnestus vaid kolmandikul või veerandil juhtudest. Erinevalt EK lastest, kes valdavalt kordasid lauseid järele veatult (vt tabel 5), vastasid KAP lapsed ligi viiendikul juhtudel elliptilise lausega (nt Emme annab $\rightarrow$ Emme annab jänkule kapsast; EK vaid $7 \%$; $t(68,18)=-4,86, p<0,01$, $d=0,68)$. Viiendikul juhtudest esines lauses lõpumorfeemi kasutamise viga $(t(62,06)=-4,77, p<0,01, d=0,66)$, sageli loobuti vastusest ( $10 \%$ juhtudest; $t(66,05)=-2,13, p<0,05, d=0,30)$. Kui EK lapsed tegid järelekorratud lauses valdavalt vaid üht tüüpi vigu, siis KAP lastel esines palju vigade kombinatsioone $(10 \% v s$. EK $0,2 \% ; t(60,14)=-3,74, p<0,01, d=0,52)$.

\section{KAP laste morfoloogilised oskused}

Samamoodi nagu EK lastel, ilmnes ka KAP laste lauseloome- ja vormikasutusoskuste vahel keskmise tugevusega positiivne seos $(r=0,49, p<0,01)$. Õigeid vorme kasutasid KAP lapsed käändsõnade puhul oluliselt vähem (vt tabel $6 ; t(70,5)=11,78, p<0,01, d=1,64)$ kui EK lapsed, seevastu osaliselt õigeid vorme arvestades ei olnud erinevus oluline $(t(85,07)=-1,38$, $p=0,17, d=0,19)$. Seega ei eristunud KAP lapsed tüve- ja lõpumorfeemi variandi ning sõnakasutuse vigade alusel EK lastest. Tegusõnade puhul kasutasid KAP lapsed EK lastest oluliselt vähem õigeid, kuid oluliselt rohkem osaliselt õigeid vorme $(t(73,0)=10,45, p<0,01, d=1,46 ; t(69,3)=-2,77$, $p<0,05, d=0,39$ ).

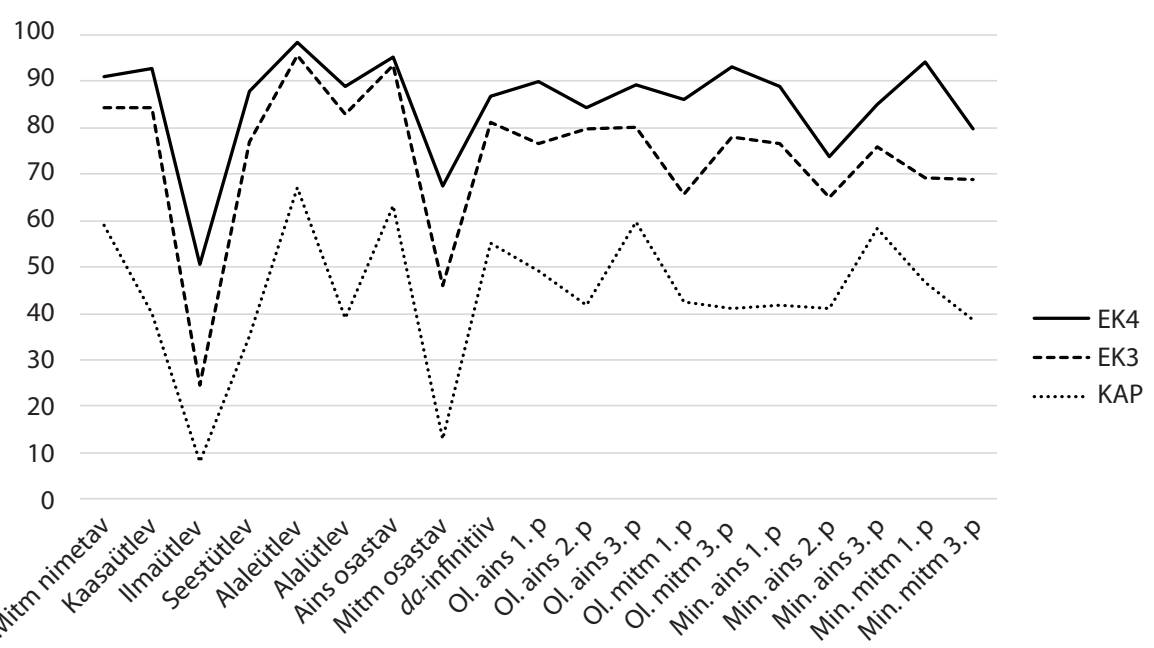

Joonis 1. Grammatiliste vormide kasutamise edukus (õigete ja osaliselt õigete vastuste protsent) 
KAP laste profiil järgib EK laste oma, kuid nende edukus on oluliselt väiksem: käändsõnavormide puhul jäi edukus vahemikku 35-40\% (v.a ilmaütlev ja mitmuse osastav kui raskeimad vormid), tegusõnavormide puhul vahemikku 39-60\%. Erinevus käände- ja pöördevormide kasutuse edukuses ei olnud KAP laste puhul oluline $(t(60)=-1,08, p=0,29, d=0,13)$.

EK ja KAP laste morfosüntaktiliste oskuste arengu võrdluse seisukohast pakkus huvi ka morfoloogiavigade iseloom. Kuna EK4 sooritus oli edukas, siis analüüsiti ainult EK3 ja KAP laste vigu kolme kõige enam raskusi valmistanud käändevormi (mitmuse osastava, ilmaütleva, seestütleva) kasutamises. Pöördevormidest valiti viis vormi nii, et esindatud olid da-infinitiiv, erinevad aja- ja pöördevormid ning arvud (oleviku ainsuse 1. pööre ja mitmuse 3. pööre, mineviku ainsuse 2. pööre ja mitmuse 3. pööre). Vigade analüüsist selgus, et EK3 ja KAP lapsed tegid sarnaseid vigu. Üle 50\% juhtudest kordasid lapsed uurija esitatud lauset (nt uurija: Konn tahab kammida. Tal ei ole kammi. Konn ei saa kammida ilma ...; laps: Tal ei ole kammi) või jätsid vastamata. Sageduselt järgnes morfeemi asendamine (tassiga $\rightarrow$ tassita; EK3 42\%, KAP 31\%) ja algvormi/tüve kasutamine, st morfeemi ärajätt (konn $\rightarrow$ konnast; kammi $\rightarrow$ kammivad; EK3 5\%, KAP 14\%). KAP lastel avaldus tendents kasutada EK3 lastest mõnevõrra sagedamini algvormi või verbitüve, kuid erinevus lasterühmade vahel ei osutunud oluliseks.

\section{Arutelu}

Uurimuses vaatlesime eakohase ja hilistunud kõnearengu grammatilisi profiile lauseloome ja grammatiliste vormide kasutuse suunatud esilekutsumise kaudu. Uurimistulemuste põhjal selgusid olulised erinevused 3- ja 4aastaste laste oskustes. Hilistunud kõnearengu korral oli profiil sarnane eakohase arenguga, sarnanedes nooremate laste omaga.

\section{3-4aastaste laste lauseloomeoskused}

Laste lauseloomet uuriti eri tüüpi ülesannetega, millest esimene - lause suunatud kasutamine uurija tegevuse alusel - võimaldas suuremat variatiivsust laste vastustes kui järelekordamine. Kinnitust leidis hüpotees, et 4aastased lapsed moodustavad testilaadses olukorras eri tüüpi liht- ja liitlauseid edukalt. Tulemus on kooskõlas Leiwo (1993), Huttenlocheri jt (2002) ja Steffani (2007) andmetega, mille kohaselt on 4aastaste kõnes liitlauseid 7-35\%. Eri tüüpi laiendeid sisaldavate lihtlausete, aja- ja sihitispõimlause, rind- ja koondlause järelekordamisel eksisid 4aastased harva, jättes ära 
fakultatiivseid laiendeid või asendades sõnu nii, et lause tähendus ja tüüp ei muutunud. Moodustades lauseid uurija tegevuse alusel, jätsid nad järelekordamisega võrreldes oluliselt sagedamini ära aluse, fakultatiivse laiendi või kasutasid aluse asemel asesõna, moodustades siiski enamasti tervikliku (kuid lühema) lause.

Oluliselt suuremaid raskusi valmistas lauseloome 3aastastele lastele. Järelekordamisel ilmnes tendents jätta ära obligatoorseid lauseliikmeid ja kasutada kuuldud lause asemel lihtsama struktuuriga lauset. EK3 laste kõne situatiivsus (st lause mittemõistetavus väljaspool tegevusolukorda) oli oluliselt suurem kui EK4 lastel. Samuti valmistas EK3 lastele suuremaid raskusi uurija tegevuse mõistmine, see aga tingis ebaadekvaatsete kirjelduste suurema osakaalu vastustes. Ka varasemates uurimustes (Klein, Moses, \& Jean-Baptiste, 2010) on leitud, et väikelastele on esilekutsutud lauseloome ülesande täitmine keeruline. Probleemiks osutub uurija tegevuse vähene usutavus ja arusaadavus. Täiskasvanuga jagatud tegevuskontekst ei eelda pikkade ja terviklike lausete kasutamist, laps pigem kommenteerib tegevust. Siiski sobisid ligi pooltel juhtudest (järelkõnes ligi 60\%) EK3 iseseisvalt moodustatud laused olukorda. Võrreldes tulemusi lausemallide kaupa, selgus, et 3aastastel lastel on kujunemas oskus laiendada verbi korraga mitme laiendiga (vt ka Argus, 1995; Leiwo, 1993). Raskeimateks lihtlausemallideks olid kolme obligatoorse laiendiga (alus, määrus, sihitis) baaslaused, edukamad oldi verbi laiendamisel vahendi- või kohamäärusega (juhul, kui kohasuhe oli selgesti tajutav, vrd sisse, peale ja taha). Järelkõneülesandes ilmnes sama tendents, kuid seal osutusid raskeimateks liitja koondlaused, mis tulevad laste kõnesse hiljem (eesti lastel 3. eluaastal), kuna vajadus väljendada erinevaid seoseid tegevuste vahel on seotud kõne dekontekstualiseerumisega (Argus, 1995; Steffani, 2007). 3aastase lapse kõne on aga veel tugevasti seotud kontekstiga, millele viitas ka elliptiliste lausete ja asesõnade rohke kasutus uurimisolukorras. Niisiis leidis kinnitust oletus, et 3aastastel avalduvad veel mõned süntaksi varasele arengule omased tendentsid, 4aastaste laste lauseloomes on aga juba toimunud oluline arenguhüpe.

\section{3-4aastaste laste morfoloogiliste vormide kasutamise oskused}

Keskmise tugevusega seos lauseloome ja vormikasutuse tulemuste vahel kinnitas varem leitud seaduspärasust, et süntaktiliste ja morfoloogiliste oskuste areng kulgeb põimunult (Bittner et al., 2003; Dressler, 2005). Kooskõlas püstitatud hüpoteesiga selgus, et 4aastased lapsed on nii pöörd- kui ka käändsõnamorfoloogia uuritud vormide piires valdavalt omandanud. Täpsemalt ei analüüsitud tüve- ja lópumorfeemi variantide kasutusvigu, 
samuti ei võimaldanud meetod uurida mitmuse 2. pöörde oleviku- ja minevikuvormi ning kõiki käändevorme kõigis funktsioonides. Viimaste valikul jäeti välja varasematel andmetel (Hallap et al., 2014) selles vanuses omandatud vormid (nt sise- ja väliskohakäänded kohafunktsioonis, omastav), samuti need vormid, mille kasutussagedus on väike ja mis ilmuvad kõnesse hiljem (olev, rajav, saav). Seega ei saa teha järeldusi morfofonoloogiliste oskuste kohta, kuigi ilmnes selge tendents, et 3aastased tegid vanemate lastega võrreldes rohkem tüve- ja lõpuvariantide vigu. Kinnitust leidis oletus, et 3aastaste laste morfoloogilised oskused on alles kujunemas, kusjuures tegusõnavormide kasutuses on nende oskused ühtlasemad ja paremad kui käändsõnade puhul. Tulemus on kooskõlas Arguse $(2004,2008)$ uuringutega, kus selgus, et eesti lastel hakkab verbimorfoloogia arenema mõnevõrra varem kui noomenimorfoloogia ja ainus raskusi valmistav vorm on lihtmineviku ainsuse 2. pööre. Erinevust käänd- ja pöördsõnamorfoloogia kasutuse edukuses 4aastastel ei avaldunud.

EK3 lastele olid minevikuvormid (v.a ainsuse 1. ja 3. pööre) võrreldes olevikuvormidega raskemad. Olevikuvormidest valmistas raskusi mitmuse 1. pööre. Minevik on olevikust kognitiivselt raskem kategooria. Selgelt eristub 2. pööre, st raskem on rääkida vestluspartnerile tema lõpetatud tegevusest kui enda või kellegi kolmanda omast. Oleviku meie-vormi kasutamist mõjutab oletatavasti selle väiksem kasutussagedus võrreldes mina-, tema- ja nemad-vormidega. Tulemused lubavad järeldada, et 4aastased on omandanud lihtmineviku kategooria (erandiks on siiski mineviku ainsuse 2. pööre). Seega täpsustus Arguse ja Parmu (2010) väide, et 4. eluaastaks pole eesti lapsed veel ajakategooriat täielikult, st kõigi ajavormide (sh täis- ja ennemineviku) osas omandanud.

Kooskõlas esitatud oletusega eristusid käändevormide korral kergemad ja raskemad vormid. Nii 3- kui ka 4aastased lapsed alles õpivad kasutama ainsuse ilmaütleva ja mitmuse osastava vorme, 3aastastel on kujunemas ka seestütlev objekti funktsioonis. Ühtviisi edukalt kasutasid mõlemad rühmad alaleütlevat adressaadi ja ainsuse osastavat hulgasõna laiendi funktsioonis, samuti võib lugeda selles vanuses omandatuteks mitmuse nimetava ja ainsuse kaasaütleva käände vormid, kuigi 3aastased kasutasid neid vorme oluliselt harvemini õigesti. Mitmuse nimetava, ainsuse (lõputa) osastava ja kaasaütleva vormid on esimeste hulgas ka teiste eesti lapse keele uurijate andmetel. Samuti ilmub alaleütlev adressaadi funktsioonis kõnesse juba 2. eluaasta lõpus ja seega juba enne kohafunktsiooni (Argus, 2004; Salo, 1994). Samas ilmaütlevat ei tuvastanud Argus (2004) kuni lapse vanuseni 2 aastat ja 8 kuud. Praeguse uurimuse tulemused kinnitavad varasemaid tulemusi, mille kohaselt mõjutavad vormide ilmumist kõnesse kasutussagedus 
sisendkeeles, vormi tähendus (sh pragmaatiline tähendus) ja moodustamise regulaarsus (Argus, 2008; Dressler, 2005; Laalo, 2009).

EK3 puhul analüüsiti ka vormikasutuses esinenud vigu. Siinse uurimuse meetodist (suunatud vormimoodustus) tulenevalt loobusid lapsed raskuste korral vastamast või kordasid uurija repliiki. Lisaks avaldusid Vihmani ja Vija (2006) kirjeldatud veatüübid. Morfeemi ärajättu, mis on iseloomulik vaese morfoloogiaga keeltele ja morfoloogia omandamise varasemale etapile (Argus, 2004), esines EK lastel väga harva. Valdavalt kasutati asendust, nt mitmuse osastava puhul peamiselt ainsuse osastavat, ilmaütleva puhul kaasaütlevat, $d a$-infinitiivi asemel oleviku ainsuse 3. pööret, mineviku mitmuse 3. pöörde asemel oleviku vormi. Seega võib väita, et tegemist on nn lähedaste asendustega (ingl near miss errors), mille puhul lapsed eksivad vormi moodustamisel vaid ühes tunnuses (nt arv, aeg). Lukácsi jt (2010) järgi on see iseloomulik rikka morfoloogiaga keelte omandamisele.

\section{Kõne arengu peetusega laste kõne morfosüntaktiline profiil}

Selle lasterühma puhul püstitati kaks hüpoteesi. Esmalt oletati, et kuigi KAP lapsed jäävad kõigi uuritud oskuste poolest oluliselt maha samaealistest EK lastest, sarnaneb nende oskuste profiil eakaaslaste omaga, meenutades nooremate laste arengu eripärasid. Teiseks püüti praktilise väljundina tuua välja tunnuseid, mis eristaksid KAP lapsi eakaaslastest.

Esimene hüpotees leidis kinnitust ja tulemused toetavad varasemate uurijate seisukohti (Rescorla et al., 2000; Rescorla \& Roberts, 2002; Rescorla \& Turner, 2015). Kõigis uuritud oskustes said KAP lapsed oluliselt halvema tulemuse kui EK lapsed. Analüüs lausemallide ja vormide kaupa näitas EK-sarnast oskuste profiili: iseseisvas lauseloomes olid raskeimad mitut laiendit sisaldavad lihtlaused või laused, mille aluseks olev tegevusolukord osutus raskesti mõistetavaks, seevastu järelkõnes ei suudetud enamikul juhtudel korrata põim- ja koondlauseid, kuid märkimisväärselt paremini ei õnnestunud ka 2-3 laiendiga baaslausete kordamine. Seega võib järeldada, et 3-4aastastel KAP lastel on alles kujunemas baaslause, mis EK3 lastel on siiski enamasti olemas. Seda kinnitas ka laste vastusetüüpide iseloom: nad nimetasid tegevusi ja objekte, jätsid ära obligatoorseid lauseliikmeid. Iseseisvas lauseloomes ei erinenud KAP ja EK lapsed lausete situatiivsuse poolest, kusjuures KAP sarnanes selle tunnuse osas rohkem EK3ga.

Keskmise tugevusega seos lauseloome ja vormikasutuse ülesannete tulemuste vahel kinnitas, et piiratud lauseloomeoskus mõjutab morfoloogiliste oskuste kujunemist. Ka grammatiliste vormide puhul järgis KAP laste profiil EK oma: pöördevorme kasutasid KAP lapsed ühtlase edukusega, seevastu käändevormide poolest eristusid neil rasketena ilmaütlev ja mitmuse 
osastav. Niisiis olid KAP lapsed edukad nende vormide kasutamisel, mis ilmuvad kõnesse varem, kuid neile valmistasid suuremaid raskusi keelde hiljem ilmuvad vormid. Samale järeldusele jõudis Lukács oma kolleegidega (2010), kes rõhutasid ka keeltevahelisi erinevusi. Eesti keeles (nagu ungari keeleski) ei valmista tegusõnamorfoloogia käändsõnamorfoloogiaga võrreldes lastele raskusi, nagu see kipub olema inglise keeles. Inglise KAP lastele on raskeim ainsuse 3. pööre, mis aga eesti keeles on üks lihtsamaid verbivorme. Kuivõrd tegusõnamorfoloogia omandamine on KAP lastel veel algusjärgus, ei ole pöördevormide kasutus käändevormidega võrreldes veel oluliselt parem (nagu EK3 lastel).

Püstitatud hüpoteesiga EK ja KAP laste morfosüntaktiliste oskuste sarnase arenguprofiili kohta on kooskõlas ka sarnased vormikasutusvead. Erinevalt morfoloogiavaestest keeltest, millele on iseloomulik morfeemi ärajätt (Deen, 2012), domineerivad tüve- ja lõpumorfeemivariantide valiku vigade kõrval morfeemide asendused, samas kui algvormi kasutust esineb harvem. Võrreldes EK3 lastega kasutasid KAP lapsed algvormi või tüve mõnevõrra sagedamini, mida võib põhjendada morfoloogia varasema arenguetapiga (sõnatüvede kasutus on iseloomulik eesti lastele vanuses 1 aasta ja 7-8 kuud; Argus, 2007; Salasoo, 1995; Salo, 1994; Vihman \& Vija, 2006).

Uurimistulemuste põhjal eristavad KAP lapsi eakaaslastest järgmised eripärad. KAP lapsed ei olnud 3-4aastaselt jõudnud lauseloomes eakaaslastele järele (Paul \& Roth, 2011; Rescorla, 2011). Baaslause kujunematus oli peamine KAP lapsi iseloomustav tunnus. Süntaktiliste oskuste puhul avaldus erinevus EKst eriti selgelt järelkõnes, kus vigade muster näitab süntaktiliste oskuste taset, mis omakorda sõltub verbaalse infotöötluse võimest. Erinevalt EKst olid KAP lastel ülekaalus elliptilised ja agrammatilised laused. Samuti oli mõlemas lauseloomeülesandes KAP lapsi eristavaks tunnuseks veatüüpide kombineerumine samas lauses. Seega saab järelkõnevõttega efektiivselt hinnata keelelist mahajäämust (Everitt et al., 2013; Riches, 2012).

\section{Piirangud ja järeldused}

Uurimusel on mitu piirangut, mida tuleks tulemuste tõlgendamisel arvesse võtta. Esiteks, tulemused on saadud testilaadses olukorras, mistõttu võivad need erineda laste spontaanse kõne alusel tehtud uuringute tulemustest. Teiseks, meetod, mis võimaldas efektiivselt uurida suurt hulka lapsi, seadis piirangu keelematerjali mahule ja esinduslikkusele keelesüsteemi seisukohalt. Materjali valikul lähtuti eeskätt lapse töövõimest ja mängulise/ visuaalse esitamise põhimõttest, mitte niivõrd tüüpkondadest ja lause- 
mallidest, mistõttu ei saa teha järeldusi kõigi keeles esinevate grammatiliste kategooriate kohta. Kolmandaks, uurimuses ei analüüsitud tüve- ja lõpuvariantide kasutusvigu, mida peetakse selles vanuses eakohaseks ja lapsi mitte-eristavaks tunnuseks (Argus, 2008; Hallap et al., 2014). Neljandaks, 3aastaste KAP laste väike arv ei võimaldanud võrrelda EK ja KAP lapsi vanuste kaupa, kuid seda oleks mõttekas teha edaspidi.

Tulemused täiendavad olemasolevaid teadmisi eesti laste grammatiliste oskuste varasest arengust, mida on senini uuritud peamiselt 2- ja 3aastaste laste näitel. On oluline, et mitmed juhtumiuuringutes avaldunud tendentsid leidsid kinnitust suurel valimil. Kolme lasterühma võrdlus lubab teha järeldusi eesti laste grammatiliste oskuste kujunemise seaduspärasuste kohta. Uurimistulemuste alusel saavad laste kõne arengut hindavad spetsialistid eristada 3-4 aasta vanuses laste grammatika arengule tüüpilisi ja ebatüüpilisi tunnuseid, mis võimaldavad KAP lapsi varakult märgata ja nende arengut toetada.

\section{Kasutatud kirjandus}

Argus, R. (1995). Ühe eesti lapse lausemoodustuse areng. A. Künnap (toim.), Minor Uralic languages: Grammar and lexis (lk 47-53). Tartu: Tartu Ülikooli Kirjastus.

Argus, R. (2004). Eesti keele käändesüsteemi omandamine: esimestest sõnadest miniparadigmadeni. Emakeele Seltsi aastaraamat, 49, 23-49.

Argus, R. (2007). Eesti keele verbi ajamorfoloogia ja aspektilisuse omandamisest. Emakeele Seltsi aastaraamat, 52, 7-32.

Argus, R. (2008). Eesti keele muutemorfoloogia omandamine (doktoritöö). Tallinna Ülikool, Tallinn.

Argus, R., \& Parm, S. (2010). Eesti keele ajakategooria omandamisest - ajavormid ja ajasõnad. Eesti Rakenduslingvistika Ühingu aastaraamat, 6, 25-41. doi: http://dx.doi.org/10.5128/ERYa6.02

Bittner, D., Dressler, W. U., \& Kilani-Schoch, M. (2003). Introduction. In D. Bittner, W. U. Dressler, \& M. Kilani-Schoch (Eds.), Development of verb inflection in first language acquisition: A cross-linguistic perspective (pp. 7-38). Berlin: Mouton de Gruyter. doi: http://dx.doi.org/10.1515/9783110899832.vii

Deen, K. U. (2012). The morfosyntax interface. In L. Bavin (Ed.), Cambridge handbook of child language (pp. 259-280). Cambridge: Cambridge University Press.

Desmarais, C., Sylvestre, A., Meyer, F., Bairati, I., \& Rouleau, N. (2008). Systematic review of the literature on characteristics of late-talking toddlers. International Journal of Language \& Communication Disorders, 43(4), 361-389. doi: http://dx.doi.org/10.1080/13682820701546854

Dressler, W. U. (2005). Morphological typology and first language acquisition: Some mutual challenges. In G. Booij, E. Guevara, A. Ralli, S. Sgroi, \& S. Scalise (Eds.), Morphology and linguistic typology. On-line Proceedings of the Fourth Mediterranean Morphology Meeting. Retrieved from https://geertbooij.files.wordpress.com/2014/02/mmm4-proceedings.pdf. 
Everitt, A., Hannaford, P., \& Conti-Ramsden, G. (2013). Markers for persistent specific expressive language delay in 3-4-year-olds. International Journal of Language \& Communication Disorders, 48(5), 534-553. doi: http://dx.doi.org/10.1111/1460-6984.12028

Grimm, H., \& Schöler, H. (1991). Heidelberger Sprachentwicklungstest (HSET). Retrieved from http://nibis.ni.schule.de/ infosos/hset.htm.

Hallap, M., Padrik, M., \& Raudik, S. (2014). Käändevormide kasutusoskus eakohase arenguga vene-eesti kakskeelsetel ning spetsiifilise kõnearengu puudega ükskeelsetel lastel. Eesti Rakenduslingvistika Ühingu aastaraamat, 10, 73-90. doi: http://dx.doi.org/10.5128/ERYa10.05

Hallap, M., Padrik, M., \& Raudik, S. (ilmumas). 3-4-aastaste laste kõnetest. Tartu: Studium.

Hawa, V. V., \& Spanoudis, G. (2014). Toddlers with delayed expressive language: An overview of the characteristics, risk factors and language outcomes. Research in Developmental Disabilities, 35(2), 400-407. doi: http://dx.doi.org/10.1016/j.ridd.2013.10.027

Huttenlocher, J., Vasilyeva, M., Cymerman, E., \& Levine, S. (2002). Language input and child syntax. Cognitive Psychology, 45(3), 337-374. doi: http://dx.doi.org/10.1016/S0010-0285(02)00500-5

Kapanen, A. (2014). Sissevaade varasesse eesti keele süntaksi omandamisse. Eesti Rakenduslingvistika Ühingu aastaraamat, 10, 139-155. doi: http://dx.doi.org/10.5128/ERYa10.09

Klein, H. B., Moses N., \& Jean-Baptiste, R. (2010). Influence of context on the production of complex sentences by typically developing children. Language, Speech and Hearing Services in Schools, 41(3), 289-302. doi: http://dx.doi.org/10.1044/0161-1461(2009/08-0080)

Korpilahti, P., \& Eilomaa, P. (2012). Kettu. 3-vuotiaan puheen ja kielen arviointimenetelmä. Helsinki: LaCo, Language \& Communication Care Oy.

Laalo, K. (2003). Early verb development in Finnish: A preliminary approach to miniparadigms. In D. Bittner, W. Dressler, \& M. Kilani-Schoch (Eds.), Development of verb inflection in first language acquisition: A cross-linguistic perspective (pp. 323-350). Berlin: Mouton de Gruyter. doi: http://dx.doi.org/10.1515/9783110899832.323

Laalo, K. (2009). Acquisition of case and plural in Finnish. In U. Stephany \& M. D. Voeikova (Eds.), Development of nominal inflection in first language acquisition: A cross-linguistic perspective (pp. 49-90). Berlin: Mouton de Gruyter. doi: http://dx.doi.org/10.1515/9783110217117.49

Leiwo, M. (1993). Lapse keeleline areng. Tallinn: Tallinna Pedagoogikaülikooli Kirjastus.

Letts, C., Edwards, S., Schaefer, B., \& Sinka, I. (2014). The new Reynell developmental language scales: Descriptive account and illustrative case study. Child Language Teaching and Therapy, 30(1), 103-116. doi: http://dx.doi.org/10.1177/0265659013492784

Lukács, Á., Leonard, L. B., \& Kas, B. (2010). Use of noun morphology by children with language impairment: The case of Hungarian. International Journal of Language and Communication Disorders, 45(2), 145-161. doi: http://dx.doi.org/10.3109/13682820902781060 
Padrik, M. (2014). Keelelise arengu puuded lastel. M. Padrik \& M. Hallap (toim.), Kõne- ja keelepuuded lastel ja täiskasvanutel (lk 129-219). Tartu: Tartu Ülikooli Kirjastus.

Paul, R., \& Roth, F. P. (2011). Characterizing and predicting outcomes of communication delays in infants and toddlers: Implications for clinical practice. Language, Speech, and Hearing Services in Schools, 42, 331-340.

doi: http://dx.doi.org/10.1044/0161-1461(2010/09-0067)

Polišenská, K., Chiat, S., \& Roy, P. (2015). Sentence repetition: What does the task measure? International Journal of Language \& Communication Disorders, 50(1), 106-118. doi: http://dx.doi.org/10.1111/1460-6984.12126

Rescorla, L. (2011). Late talkers: Do good predictors of outcome exist? Developmental Disabilities Research Reviews, 17(2), 141-150. doi: http://dx.doi.org/10.1002/ddrr.1108

Rescorla, L., Dahlsgaard, K., \& Roberts, J. (2000). Late-talking toddlers: MLU and IPSyn outcomes at 3;0 and 4;0. Journal of Child Language, 27(3), 643-664. doi: http://dx.doi.org/10.1017/S0305000900004232

Rescorla, L., \& Roberts, J. (2002). Nominal versus verbal morpheme use in late talkers at ages 3 and 4. Journal of Speech, Language, and Hearing Research, 45(6), 1219-1231. doi: http://dx.doi.org/10.1044/1092-4388(2002/098)

Rescorla, L., \& Turner, H. L. (2015). Morphology and syntax in late talkers at age 5. Journal of Speech, Language, and Hearing Research, 58(2), 434-444. doi: http://dx.doi.org/10.1044/2015_JSLHR-L-14-0042

Rice, M. L., Taylor, C. L., \& Zubrick, S. R. (2008). Language outcomes of 7-year-old children with or without a history of late language emergence at 24 months. Journal of Speech, Language, and Hearing Research, 51(2), 394-407.

doi: http://dx.doi.org/10.1044/1092-4388(2008/029)

Riches, N. G. (2012). Sentence repetition in children with specific language impairment: An investigation of underlying mechanisms. International Journal of Language \& Communication Disorders, 47(5), 499-510.

doi: http://dx.doi.org/10.1111/j.1460-6984.2012.00158.x

Rätsep, H. (1978). Eesti keele lihtlausete tü̈̈bid. Tallinn: Valgus.

Salasoo, T. (1995). Morfoloogiliste tunnuste esmakasutus ühe lapse arenevas keeles. Keel ja Kirjandus, 4, 239-252.

Salo, A. (1994). Muutelõppude ilmumine ühe Eesti lapse keelde vanuses 1.5-2.5. J. Toivainen \& K. Toivainen (toim.), Ensikielenä suomalaiskieli. Turun yliopiston suomalaisen ja yleisen kielitieteen laitoksen julkaisuja, 46 (s. 22-29). Turku: Turun Yliopisto.

Steffani, S. A. (2007). Identifying embedded and conjoined complex sentences: Making it simple. Contemporary Issues in Communication Science and Disorders, $34,44-54$.

Zambrana, I. M., Ystrom, E., \& Pons, F. (2012). Impact of gender, maternal education, and birth order on the development of language comprehension: A longitudinal study from 18 to 36 months of age. Journal of Developmental and Behavioral Pediatrics, 33(2), 146-155. doi: http://dx.doi.org/10.1097/DBP.0b013e31823d4f83

Vihman, M. M., \& Vija, M. (2006). The acquisition of verbal inflection in Estonian: Two case studies. In N. Gagarina \& I. Gülzow (Eds.), The acquisition of verbs and their grammar: The effect of particular languages (pp. 263-295). Dordrecht: Springer. 


\title{
Grammatical profile of three- to four-year-old Estonian children
}

\author{
Marika Padrik $^{\mathrm{a} 1}$, Merit Hallap ${ }^{\mathrm{a}}$, Signe Raudik ${ }^{\mathrm{a}}$ \\ ${ }^{a}$ University of Tartu, Institute of Education
}

\section{Summary}

\section{Introduction}

Morphosyntactic skills are important marker of child language development. The acquisition of the Estonian language has mainly been studied by longitudinal case studies on the basis of the spontaneous speech data (Argus, 1995, 2004, 2007, 2008; Kapanen, 2014; Salo, 1994; Vihman \& Vija, 2006). There are preliminary data on the early acquisition of syntax (Argus, 1995; Kapanen, 2014), Estonian case system (Argus, 2004, 2008; Hallap et al., 2014; Salo, 1994) and verbal morphology (Argus, 2007, 2008; Salasoo, 1995; Salo, 1994).

About $10-15 \%$ of children are delayed in their early expressive language skills despite their normal nonverbal cognitive ability, adequate hearing, and typical personality development. The term late talkers is suggested to refer to these children (Desmarais et al., 2008). Late talkers begin their syntax and morpheme acquisition processes at a later age than do typically developing children, and at the age of 3 to 4 they are still delayed in grammatical skills, but not deviant in their development (Rescorla, 2011; Rescorla et al., 2000; Rescorla \& Roberts, 2002). The data about language acquisition in case of Estonian late talkers is absent at the moment.

The aim of the study was to describe and compare grammatical profiles of three- to four-year-old Estonian children with typical and delayed speech development, as well as to identify markers that distinguish children at risk for delayed speech development.

The following hypotheses were set up for the research:

1. We assumed that four-year-old Estonian children used different simple and composite sentence structures (Huttenlocher et al., 2002; Leiwo, 1993; Steffani, 2007). In the case of three-year-old children some tendencies typical of early syntax acquisition, such as the preliminary extending of a subject and a predicate as well as using two simple sentences 
to convey basic verbal argument structure constructions (subject-verbobject) will occur (Kapanen, 2014).

2. We assumed that four-year-old children have acquired Estonian verbal and nominal inflections, i.e use them correctly in $80 \%$ contexts, while three-year-olds coin word forms by analogy and still show production errors. We proposed that in Estonian as morphologically rich language morphophonemic and commission errors predominated over errors of omission (Hallap et al., 2014; Vihman \& Vija, 2006).

3 . We assumed that morphosyntactic skills of late talkers were significantly lower than those of children with typical language development, while the profile of skills was similar, i.e. both groups made errors in the same word forms (Rescorla \& Roberts, 2002; Rescorla \& Turner, 2015).

4. We assumed that late talkers used more simple sentence structures than typically developing peers both at three and four years of age (Rescorla et al., 2000) and that sentence repetition/imitation was a good marker for delayed speech development (Everitt et al., 2013). Considering language specifics, we assumed that late talkers exhibited difficulties both in verbal and nominal morpheme use (Argus, 2008; Dressler, 2005; Lukács et al., 2010), at the same time types of errors made by late talkers were similar to those made by children with typical development.

\section{Method}

This study reports age $3(\mathrm{~N}=149)$ and $4(\mathrm{~N}=186)$ syntax and morphology skills in typically developing Estonian monolingual children compared to late talkers $(\mathrm{N}=61)$ aged three to four. Grammatical skills were measured by tasks from Speech and Language Assessment Test for three to four years old Estonian children (Hallap et al., in press), incl. structured elicitation and elicited imitation methods. Tasks assessed the children's use of eight case forms and 11 verb forms. Different simple and composite sentence structures were used in production and imitation tasks measuring syntactic skills.

\section{Major results and discussion}

\section{Syntactic skills of typically developing three- to four-year-old children}

The hypothesis that four-year-old typically developing children produce different simple and composite sentences was confirmed. The results of three-year-olds were significantly lower than those of four-year-olds. Simple 
sentences including three obligatory arguments were the most difficult ones, while sentences with one adverbial (expressing place or means of action) were successfully produced. Sentence imitation was difficult in case of simple sentences with several arguments, sentences with recurrent parts, and composite sentences - all acquired at a later age (Argus, 1995; Steffani, 2007). It can be concluded that skills to extend the verb with several arguments is developing in three-year-olds. The frequent use of elliptical sentences and pronouns by three-year-olds refers to the strong connection with the context in sentence production in test situations. Thus, some tendencies of early syntax appeared in sentence production by three-year-olds.

\section{Morphological skills of typically developing three- to four-year-old children}

Moderate correlation between the results of tasks measuring syntactic and morphological skills confirms that those skills develop in parallel (Bittner et al., 2003; Dressler, 2005). The results revealed that four-year-olds have acquired verbal and noun morphology (as far as studied morphemes are concerned) and the only form children experienced some difficulties with was past present, 2sg. Morphological skills of three-year-olds are still developing. Noteworthy is the fact that skills in using verbal inflection were better and more homogeneous than those of using nominal inflection. These results are in line with studies by $\operatorname{Argus}(2004,2008)$ according to which inflectional morphology starts to develop in nominals later than in verbs. Past tense forms (except 1sg and 3sg) were more difficult to produce than present forms. However, four-year-olds have mastered the past tense category of verb forms (except for $2 \mathrm{sg}$ ). The results clearly revealed that some noun forms were easier (allative, partitive sg, nominative $\mathrm{pl}$ and comitative sg) while others appeared to be more difficult (abessive, partitive $\mathrm{pl}$ and elative) to produce. Results confirm the conclusions from earlier studies (Argus, 2008; Dressler, 2005; Laalo, 2009) that the acquisition of morphology is influenced by word frequency, input, semantics and regularity of inflection.

\section{Morphosyntactic profile of late talkers}

Late talkers differed from typically developing children in all measures. Results revealed that the production of simple sentences by late talkers was only developing at the age of three and four. The pattern of errors made by late talkers was different from the one of typically developing peers: in sentence repetition tasks most of the sentences were elliptical and with errors 
of morpheme use. In the sentence elicitation task, late talkers just named the action and object without actually producing the sentence. It was typical of late talkers to make several types of errors in producing one sentence. The results confirmed that sentence repetition was a useful marker for processing deficits of late talkers (Everitt et al., 2013; Riches, 2012). Also, in nominal inflection the profile of late talkers was similar to the one of typically developing children. Late talkers successfully used those word forms that are acquired earlier and had difficulties with those that come to use later as abessive and partitive plural. Verbal morphology was not more difficult than nominal. One of the easiest forms to produce was the third singular present that is difficult for English and easy to Hungarian children (Lukács et al., 2010). Apart from morphologically poor languages, in Estonian morphophonemic and commission errors dominated, compared to errors of omission. Still, late talkers used also some stems in lieu of inflectional affixes, that usually occur during the premorphological phase of morphology acquisition (Argus, 2007; Vihman \& Vija, 2006). Thus, the suggestion that the pattern of acquisition by late talkers was similar to that of typical development but more protracted was confirmed (Rescorla \& Roberts, 2002; Rescorla \& Turner, 2015).

Results update current knowledge about the development of early grammatical skills by Estonian children. Several tendencies revealed in earlier case studies were confirmed by larger number of subjects in this study. Comparison of three children groups allows us to make some conclusions about the regularities of grammar development in Estonian children. Results enable specialists working with three- to four-year-old children to differentiate between typical and atypical features of grammar development. This in turn contributes to early identification and intervention.

Keywords: delayed language acquisition, typical language development, grammatical profile 